\title{
6G Technologies - How Can It Help Future Green Business Model Innovation
}

\author{
Peter Lindgren
}

CGC - Aarhus University, Denmark

E-mail:peterli@bteh.au.dk

\author{
Received 19 July 2021; Accepted 05 December 2021;
}

Publication 11 February 2022

\begin{abstract}
In the last few years businesses have been motivated and pushed by governments and global society on innovating and developing Green Business Models. However, Reconfiguring, designing and developing green business models to become efficient and valuing Green Business Models have shown to be much more complex than expected. It includes balancing monetary and non monetary value formulas of business models in symbiosis. Not just for the single business - but for businesses in their entire value network.

This includes security challenges related to securing that green business models really are green - and not based on greenwashing. As green business models demand in long term perspective a very open business model innovation approach, it calls for stronger and new security technologies. Protection of IPR's of Business Models and businesses competences, so they are not one to one copied with out giving value back to "the Business Model designer" and the rightful original owner of the business models is a major security challenge related to green business models.

Green Business Models and Green business Model Innovation calls therefore for new and more advanced security approach, technologies and understanding. Previous business model innovation security practice and systems cannot fully offer these solutions - but $6 \mathrm{G}$ of wide-area wireless
\end{abstract}

Journal of ICT Standardization, Vol. 10_1, 11-38.

doi: 10.13052/jicts2245-800X.1012

(C) 2022 River Publishers 


\section{P. Lindgren}

security technologies - as an umbrella - gives hope and can potentially play major role with new security technologies supported by AI, AR and blockchain technologies. This evolvement is highly and urgent needed to support the success of our society's green transformation.

The paper document through Nordic green business model cases some of the above mention security challenges that green business models and green business model innovation stand in front of and need to innovate solutions for. The paper discuss and propose how $6 \mathrm{G}$ and related technologies could help.

Keywords: 6G green business models, strategic green multi business model innovation, , green business model innovation, green business model development, green business model parameters, green business model measurement, the green wall.

\section{Introduction}

$6 \mathrm{G}$ will be the sixth generation of wide-area wireless technology. Before this can be a reality a series of enabling technologies need to be built up to support it - amongst others several new security technologies. One of these areas that call for intense technology innovation and development is security related to green business models (GBM) and green business model innovation (GBMI).

The green transformation in businesses is going to slow according to experts and investors $[1,2]$. Therefore, EU propose recently a new disruptive plan for green transformation [3] for 2050. An ambitious green transformation plan with a budget of more than 100 Billion EUR. The ambition is to give more value back to the planet than we take today - very much related to the Brundtland Commissions report and vision [4]. However, EU also see a very strong business for EU in investing in the green transformation plan but little have been addressed on security issues of the green transformation both related to humans, species and businesses.

The EU transformation plan includes a variety of initiatives that address many different GBM parameters amongst others - How to use materials and resources?, Life Cycle Analysis (LCA), Type of energy used - black and green energy, energy efficiency, recycling of materials, waste, waste reduction, waste construction, pollution, low carbon emission, acceptable GBM archetypes and innovation, new collaboration types, sustainable business models (SBM), circular business models (CBM) and not least UN 17 Goals [5]. 


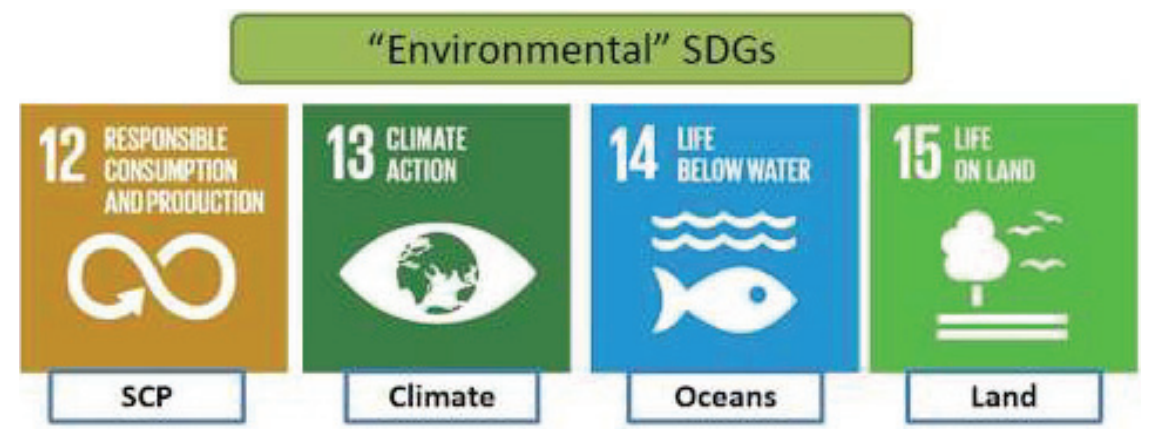

Figure 1 The Sustainable Business Model and the "environmental SDGs Narrow approach.

All topics and terms are related to the discussion on GBM and GBMI and are expected to give large competitive advantage and a greener society. All topics are more or less being related to the term green, green economy, green business, GBM's, GBMI and green technology - and particular the environmental part of the UN 17 Goals as shown in Figure 1.

Particular the environmental part we relate to in our research on GBM as sustainable business models [6] and circular business model [7] communities seems not to have done much progress on GBM lately. They have tried to embed the GBM into their terms and vocabularies as shown in Figure 2 however with great difficulties and not large success. Further they do not consider both the "TO BE" GBM's (dotted BM Cube figur) and "AS IS" GBM (Figure 2) equally in their initiative on greening businesses BM's. Our investigations shows clearly that most "greening business model innovation work" has to be focused on AS IS BM's - reengineering of BM's - as it is here that businesses major burden and challenges on greening businesses BM's lays. It is also here that most security issues lays related to GBMI.

Especially when sustainable and circular business models turns out not to be green - green washing [8]. Greenwashing refers to when businesses mislead their user, customers and even investors by making them believe that a BM they offer, or the business itself is environmentally friendly or green, when it is not. This can be very secured documented when deeper investigated and documented both in a short, long term and value network perspective. The green parameters and definitions accordingly, becomes however in this cases very difficult to measure and secure correct measurement. When there is no open and secure access to all the business and their related businesses BM's measurements and security of measurements, then it becomes very difficult to do fast and precise GBMI. Therefore, there is a large need for new and 


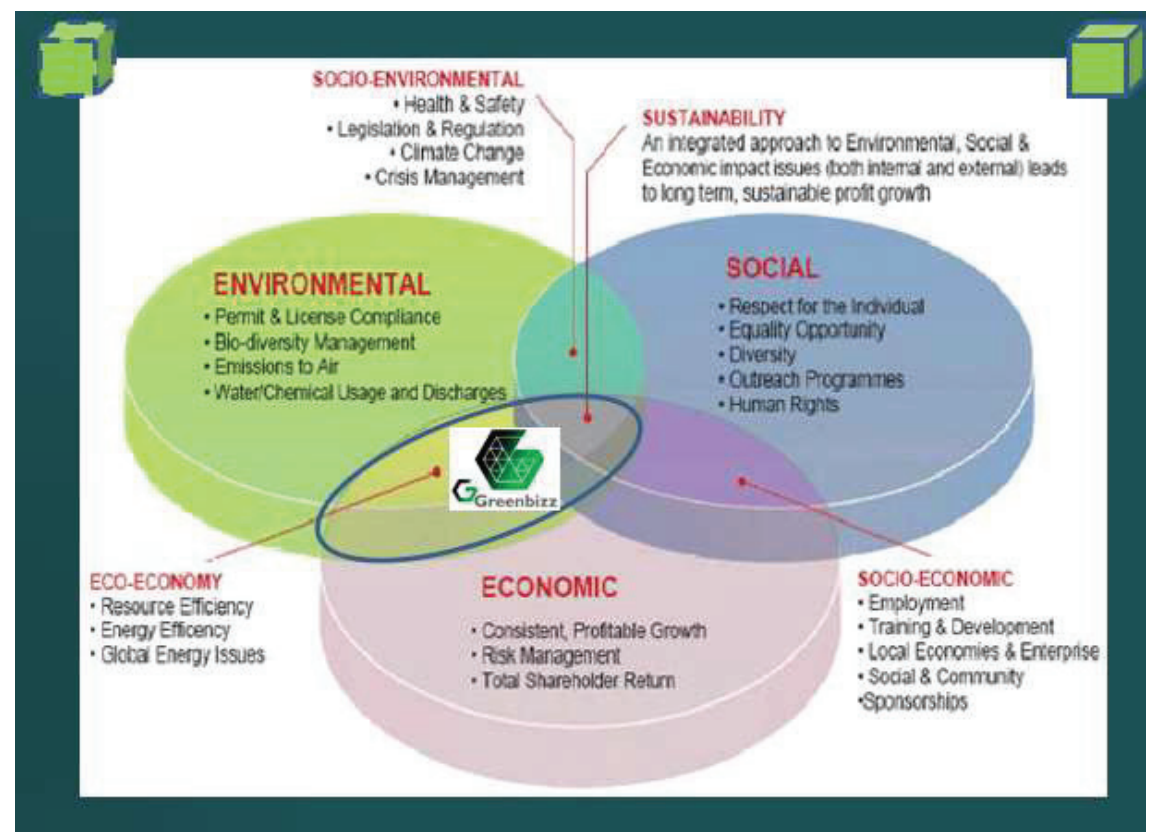

Figure 2 Green Business Models related to discussed topics in literature and praxis.

more advanced technologies based on the promises of $6 \mathrm{G}$ technologies - low latency, $6 \mathrm{G}$ will operate at $95 \mathrm{GHz}$ to 3 terahertz $(\mathrm{THz})$. At those wavelengths, 6G will deliver speeds 1,000 times faster than $5 \mathrm{G}$ that can help measure, document and secure that a GBM is really green - down to the very small BM component level and across the business value network's BM's - within internet time.

Further when GBMI turns into be measured in a more broad GBM perspective, as shown in Figure 3, it becomes even more complex to measure and secure that measurements of GBM's are correct. However, 5G Makes the Internet of Things Possible and 6G is expected to speed it up. Part of the reason $5 \mathrm{G}$ is so anticipated lies in the expectation that it will finally make the Internet of Things a practical everyday reality. The frequencies used by $4 \mathrm{G}$ are too narrow and too crowded to transmit data at the speeds that smart devices need to function optimally. That's why they haven't gained widespread traction - that's going to change with $5 \mathrm{G}$, and likely again even more with 6G. 6G Opens New Frontiers of Connectivity but 5G doesn't. 5G has struggled to arrive because of its infrastructure requirements. In contrast, $6 \mathrm{G}$ will build on the infrastructure that is put down for $5 \mathrm{G}$ and enhance 

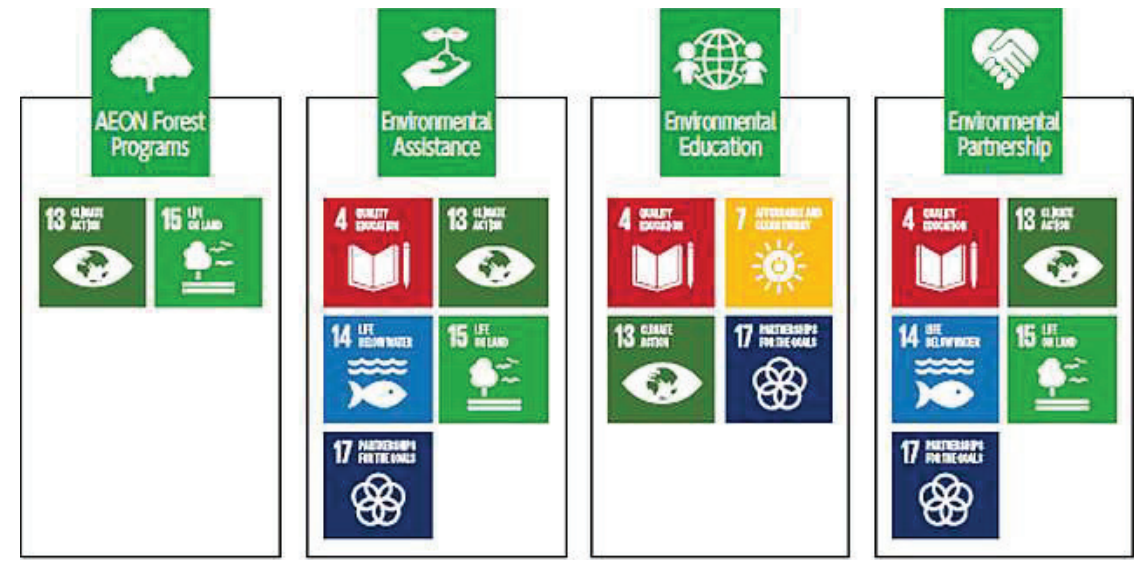

Figure 3 The Sustainable Business Model and the "environmental SDGs The very Broad approach.

connectivity radically - not just on land, but also under the sea, or even in space.

By leveraging the massive bands found at the upper bounds of gigahertz and lower terahertz frequencies, businesses will have more than just faster devices. They will have genius, faster devices that can sense material, devices, species and humans down to few centimetres. Most speculations expect the sheer speeds and data capacity of $6 \mathrm{G}$ to transform connectivity on a whole, allowing businesses to connect more devices with smarter and more precise data at a rate that far exceeds anything that $5 \mathrm{G}$ will offer.

In its report on the applications of terahertz waves, the FCC noted that this extreme connectivity would allow for "centimeter-level positioning" (compared to the feet-level accuracy with 4G) and much more sophisticated data centers. This has direct impacts on things like drone fleets, robotics controls, and monitoring devices. Among the many benchmarks that Japanese business Docomo expects, 6G will achieve and include "seven-nine reliability" (99.99999\% reliability). That effectively means coverage anywhere, everywhere, and always. It described "extreme coverage" that included new boundaries over land, undersea, and even in space.

Some experts claim that $6 \mathrm{G}$ 's speed and positioning precision will finally be what allows AI to process and transmit data at the speed of a human brain. Although 5G will make artificial intelligence more accessible and capable, $6 \mathrm{G}$ is slated to transform AI with "disruptive applications" that make its presence in our world much more prominent. 
Several GBM parameters seems also to conflict each other and there is a need to make faster, more precise and secure calculations of GBM and GBMI so our businesses and society knows that we are "greening" in the benefit of humans, species and our globe. Further there is a need to make more secure scenarios of TO BE GBM's.

As already well known - if businesses do not receive green value back from their green business model value exchange with other businesses then the businesses will shrink and eventual vanish as a green business. Herein lays some of the largest advanced technology challenge and hereunder security challenges in future green business model innovation. As both the business, its value network and society in general wants and in the future will demand gain better and more secure knowledge of green business model values and transfer. They will demand security that green values really are green values and really takes place in business model value exchange - both in short and long term perspective.

In this measurement context, Table 1 shows what the CGC - Greenbizz research group initially found of GBM measurement parameters. Through our investigation of existing literature, practice and GBMI projects [9-14] we found several green business model parameters but very few parameters related to the business model dimension value formula and monetary output of GBM's.

None of these - except the Greenbizz project focused on the business monetary value formula's and if there were any earnings in greening the businesses. Businesses are challenged on the business cases of GBM's and continuously questioned on their business models - both individually and in combination with value networks. Figure 4 sketches some of the sources and challenges to GBM and green BM parameters related to the above mentioned and discussed topics.

All GBM topics as mentioned above are seen as solutions to fulfil the Global Societies vision, mission and goals to become a green economy and $\mathrm{Co} 2$ neutral society. The goal for energy efficiency and carbon reduction drive many businesses and BMES into strategies that incorporate GBM, either reconfiguration of AS IS BM to become green or design GBM to meet visions, mission and goals for low carbon and sustainable growth [6, 7]. Business and BMES we studied turned out however to innovate and implement these in very different ways and to what they believe is the "road to becoming a greener business".

A. In the direct way by e.g. greening energy production/suppling their business with sustainable alternative fuels or electricity, reducing 
Table 1 Green business model Parameters, measurement areas and Green Business Model Projects

\begin{tabular}{|c|c|c|c|}
\hline Green Business & Green Business Model & & \\
\hline Model Parameters & Sub-Parameters & Measurements and Approach & Projects Studied \\
\hline \multirow[t]{2}{*}{$\begin{array}{l}\text { Material and } \\
\text { Resources }\end{array}$} & Energy & $\begin{array}{l}\text { Reduction of energy } \\
\text { consumption or changing energy } \\
\text { consumption to more renewable } \\
\text { types of energy }\end{array}$ & $\begin{array}{l}\text { (ECSMV)(SETS II) } \\
\text { (Greenbizz) }\end{array}$ \\
\hline & $\begin{array}{l}\text { Material and } \\
\text { resources }\end{array}$ & $\begin{array}{l}\text { Reduction of material and } \\
\text { resource use Water } \\
\text { use/consumption reduction }\end{array}$ & $\begin{array}{l}\text { (SETS II), (ECSMV), } \\
\text { (CIRCit) (Greenbizz) }\end{array}$ \\
\hline Pollution & & $\begin{array}{l}\text { Reducing pollution including } \\
\mathrm{CO} 2 \text { Reduction of pollution from } \\
\text { chemicals, reduction of noise }\end{array}$ & $\begin{array}{l}\text { (SETS II), (ECSMV), } \\
\text { (CIRCit) (ECSMV), } \\
\text { (GREENBIZZ), (SET } \\
\text { II), (Monica) }\end{array}$ \\
\hline Waste Reduction & & $\begin{array}{l}\text { Reduction of waste Reduction of } \\
\text { production of waste water }\end{array}$ & (SETS II), (ECSMV) \\
\hline $\begin{array}{l}\text { Self Production } \\
\text { of Energy, } \\
\text { materials and } \\
\text { resources }\end{array}$ & & $\begin{array}{l}\text { Solar-, Wind-, Heat, Hydro } \\
\text { energy production from own } \\
\text { production facilities, Collecting } \\
\text { rainwater for use in business }\end{array}$ & $\begin{array}{l}\text { (ECSMV), } \\
\text { (Greenbizz), (SETS } \\
\text { II) }\end{array}$ \\
\hline $\begin{array}{l}\text { Circular } \\
\text { Economy }\end{array}$ & & $\begin{array}{l}\text { Recycling resources and } \\
\text { materials, recycling water, heat, } \\
\text { cradle to cradle principle, } \\
\text { reducing use of material and } \\
\text { resources in the whole life cycle } \\
\text { of a green business model }\end{array}$ & $\begin{array}{l}(\text { ECSMV })(\text { SETS } \\
\text { II), (Greenbizz), } \\
\text { (Climatorium) }\end{array}$ \\
\hline Environmental & & $\begin{array}{l}\text { Increasing Environmental quality } \\
\text { by ... reducing energy, materials } \\
\text { and water } \\
\text { consumption ... decarbonize the } \\
\text { economy and minimize or } \\
\text { altogether avoid generation of all } \\
\text { forms of waste and } \\
\text { pollution.... clean technology } \\
\text { businesses, green building } \\
\text { construction businesses, green } \\
\text { education and materials recovery } \\
\text { businesses... BM's in traditional } \\
\text { sectors with businesses that have } \\
\text { significantly greener processes or } \\
\text { operations than industry } \\
\text { standards.... Local food } \\
\text { production, urban farming }\end{array}$ & $\begin{array}{l}\text { Vancover - The } \\
\text { Greenest City }\end{array}$ \\
\hline Biodiversity & & Increasing Biodiversity & (Greenbizz) \\
\hline $\begin{array}{l}\text { UN } 17 \text { World } \\
\text { Goals }\end{array}$ & $\begin{array}{l}\text { SDG 12, 13, 14, } 15 \\
\text { (Narrow) SDG 4, } 7,12 \text {, } \\
\text { 13,14, 15, } 17 \text { (Broad) }\end{array}$ & UN 17 World Goals Approach & (Climatorium) \\
\hline
\end{tabular}




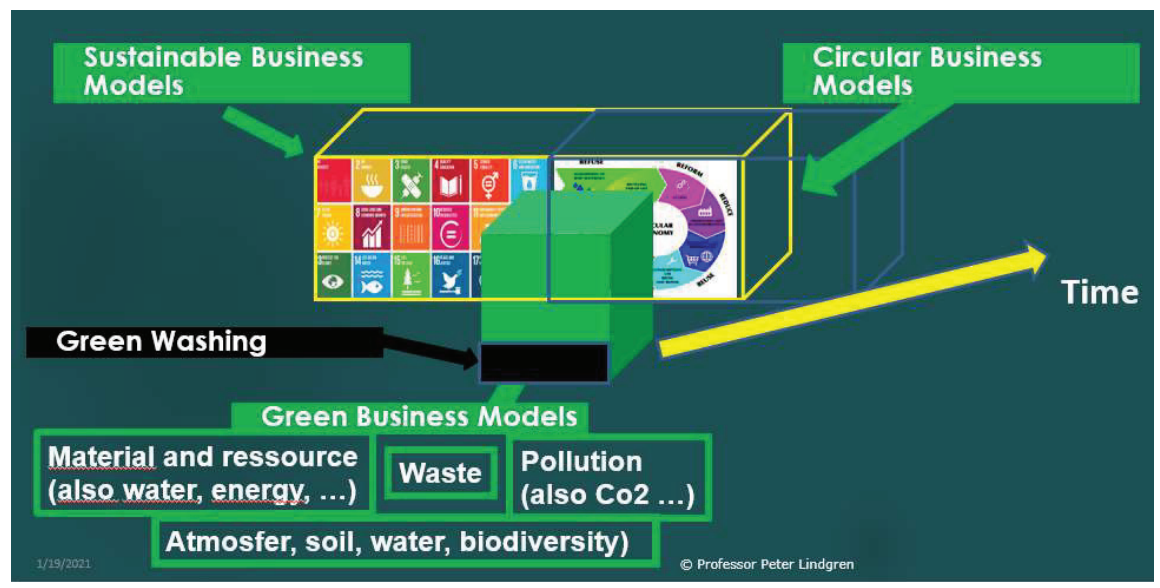

Figure 4 Green Business Model parameters related to real Green Business Model measurement topics in literature and praxis [20].

their own or their value networks energy demands for energy, changing their energy consumption from black to green energy - or more green energy $[13,15,16]$.

B. In the indirect way by e.g. using carbon displacements, applying innovative digital and satellite-based GBM, including new tools, new transport and logistic optimisation mechanisms for multimodal access, passenger and freight flows into and out of traffic hubs as airports, ports, smart cities as well as between these, facilitating access and reducing traffic and transport from/to hubs or other nodes.

C: In the value network way by collaborating with other businesses, vertical and horizontal BMES to provide e.g. energy efficiency in the entire value network (smartgrids, smart buildings, intelligent transportations systems, etc) - in new types of collaboration models - e.g. Green Business Quinto Helix networks working in symbiosis [17-19].

D. In the Cross Cutting way by improving other GBM parameters e.g. Air quality (indoor, outdoor, including decontamination from microbiological pathogens) and noise reduction by measurement, reporting and verification (MRV) by advanced use of ICT among others, 5G, 6G and satellite-based solutions.

E. In the repair way by developing new advanced technology and solutions to "repair" and reduce Co2 emmision - Draw Down Co2 [15] as 


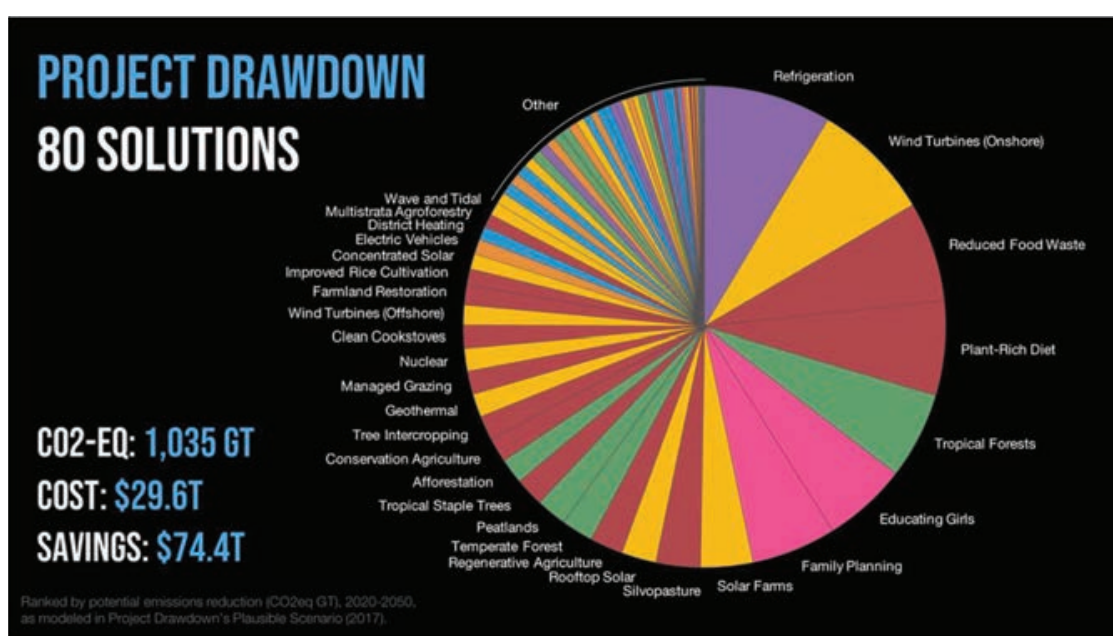

Figure 5 Project Drawdown Solutions for Climate Solutions [20].

shown in Figure 5 and proposed by the community behind Project Draw Down [20].

F. In the Greenwashing way [8] by businesses engaging in greenwashing, misleading users, customers, network, employees, stakeholders, society and others about their environmental performance or the environmental benefits of their business models.

Hereby businesses are communicating about the greenness of their business models and practices in order to reap the benefits of expanding GBM model ecosystems (GBMES). This is often done with support of advanced wireless and IOT technologies, persuasive promotion and social media technologies. However, there is no "objective technologies" and instant that measure the greenness of a BM or a business in real time, in every business model component through the whole value network. The incidence of greenwashing then becomes easier to carry out but as we regard as strategical extremely risky to businesses. Greenwashing could have profound negative effects on the business but also all above mention groups confidence in GBM's and the vision and mission of GBM. Therefore advanced security technologies that eliminates the possibility to do green washing and further are able to secure users, customers and other stakeholders that they are buying green business models, when they want and demand to buy GBM's.

We do not in particular focus on greenwashing in this paper, as we regard this approach not to be classified as a valid and sustainable strategic 
business approach and road to go. Green Business models becomes only a real and pure green business model, when it can be classified and measured green on all green BM parameters anytime and in relations with all its value networks business models. This is extremely difficult and maybe never possible to achieve. However, we believe that in Designing, reconfigure and developing GBM's advanced security technologies can play a major role to create transparency, valid measurement and security of green and hereby prevent Greenwashing. However, mitigating greenwashing is particularly challenging in a context of limited and uncertain regulation which is the reason why several businesses [16] works intensively to find and create standards and regulatives to classify GBM's. Green BM standardisation is one of the larges and most expansive business model ecosystems. However, standards of GBM's, sustainable and circular business models including UN 17 Goal standards and certificates includes several challenges and pitfalls. Amongst others they are not

- measuring in realtime

- built to measure value networks of business models

- able to measure at component level of business model

- able to track components of business models over a lifetime of the BM

- able to track GBM components that are mixed with black BM components

Further they have difficulties to measure AS IS BM's that already have embedded "black business model dimensions and components." Here - we believe - advanced wireless technologies can play an important role to measure, verify, support, control and secure GBM's in the future. 6G is supposed to fulfil the visions of $5 \mathrm{G}$ as well as to enable as shown in Figure 6:

- Wisdom connection (Intelligent connectivity with the help of AI (Artificial Intelligence)

- Depth connection (Deep connectivity) with the help of AI

- Holographic connection (Holographic connectivity) refers to seamless coverage anywhere, anytime to anybody and anything using AR (Augmented Reality)/VR (Virtual Reality) and AI.

- Ubiquitous connection (Ubiquitous connectivity) to cover Space, Air, Ground and Sea with the help of AI

Many of these expected benefits will meet the wanted requirements and challenges of GBM's. As 6G technology is designed to support higher number of mobile connections greater than the $5 \mathrm{G}$ capacity, which is about $10 \times 105$ per $\mathrm{Km}^{2}$. This means that BM dimensions, components and even 


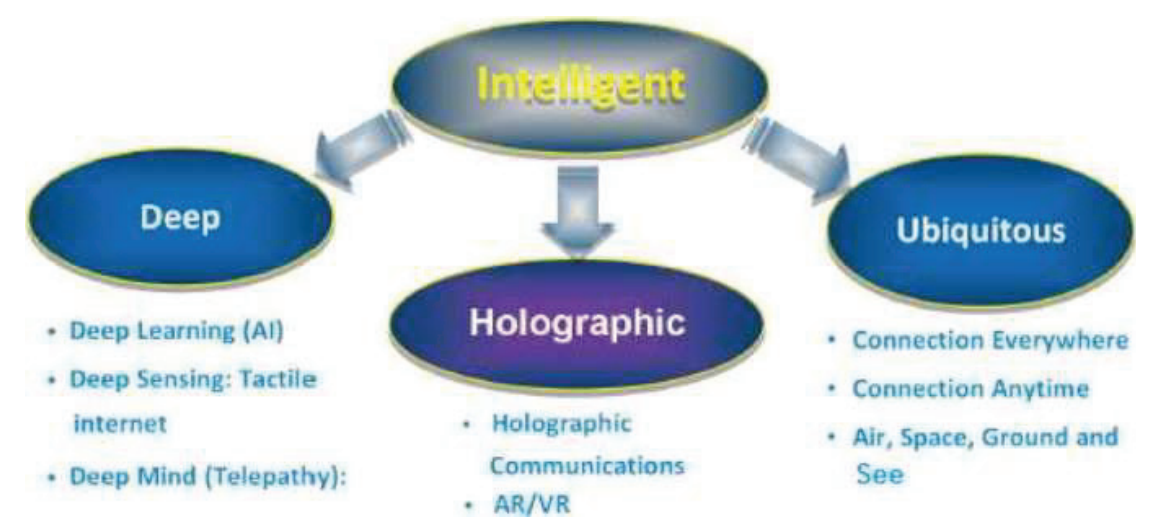

Figure 6 Benefits $6 \mathrm{G}$ technologies.

whole BM's that are not green but are related to GBM can no longer be "hided". It means that green washing becomes very difficult to practice.

6G will revolutionize the GBMI and eliminate time and space barriers through remote GBM workflow optimizations. As most of the mobile traffic is generated indoors and cellular networks have never really been designed to target indoor coverage efficiently $-6 \mathrm{G}$ will overcome these challenges using femtocells or Distributed Antenna Systems (DASs). Indoor GBM's are hereby accessible to GBM measurements indoor.

As $6 \mathrm{G}$ uses $\mathrm{THz}$ (Terahertz) frequencies, which means that $\mathrm{THz}$ waves can easily absorb moisture in the air and then becomes useful for high speed short range wireless communications in the benefit of GBMI. Terahertz offers narrow beam and better directivity resulting into more secure communication which is achieved due to strong anti interference capability. High wireless bandwidth (several tens of $\mathrm{GHz}$ ) from 108 to $1013 \mathrm{GHz}$ can deliver higher communication rate in $\mathrm{Tb} / \mathrm{sec}$. This enables potentially real time communication to the GBM and GBMI processes which no long make it impossible to measure GBM's in realtime.

AS 6G wireless uses visible lights which leverage benefits of LEDs such as illumination and high speed data communication. VLC does not produce EM (electromagnetic) radiation. Hence it is not susceptible to external EM interference. VLC will hereby help in building network security among others in GBM value network security.

As $6 \mathrm{G}$ offers very high data rate $(\mathrm{Tb} / \mathrm{sec})$ and very low latency (sub-ms), which will enable much more detail GBM data to be measured, received and analysed. 6G will virtualize additional components, such as PHY layer 
and MAC layer. Currently PHY/MAC implementations require dedicated hardware implementations. The virtualization will decrease the costs of networking equipments. This makes massively dense deployment in 6G economically feasible and will support GBMI even more.

\section{Towards Securing Green Business Models and Green Business Model Innovation}

GBM's are strongly linked to - other values - other gains and focused at solving other pains, problems, challenges and meanings than money and quantitative green business model parameters. GBM's address much other values in the value formula of BM's [21]. GBMI is about creating, capturing, delivering, receiving and consuming a multitude of other values for users, customers, networks, employees and other stakeholders - both "hard and soft values". GBMI is about appropriating as large a share as possible of both monetary and non-monetary values - and in symbiosis. GBMI is about value networks together creating GBM's and relating their BM's in a multi business model oriented approach and a new multi business model measurement framework. This means, that businesses entering the GBM domain strategically must "play" or should be motivated to "play" with more BM's at the same time - some with money and some with other values - in this papers cases - GBM values. They are today requested and often dragged into playing by the fulfilment of Green Business Model parameters. But, if any business or society succeed in cheating in this game or not playing by "the ruleset" of the green business model ecosystem approach [4] then mistrust will spread and the green busines model ecosystem will eventually fall apart. Here 6G and security can play an important role so this will not happen.

As more and more businesses face strategic challenges related to choosing a strategy or roadmap for their business green BM transformation, it becomes interesting to observe which strategies businesses actually follow today in their GBMI journey. In Table 2, based on our preliminary investigations in 2020/2021 of 109 Danish Small and Medium size businesses GBMI projects and processes, we discovered their single green business model strategies. All businesses were screened by a screening questionnaire. All businesses were interviewed personally and filled out the screening questionnaire together with the interviewer. All data from this screening was carefully analysed and grouped into different strategy categories as seen in Tables 2 and 3. Our investigation shows that most GBMI strategies are focused on limited numbers of Business Model dimensions. 
Table 2 Single green business model innovation related to business model dimensions

\begin{tabular}{|c|c|c|c|c|c|}
\hline \multirow{4}{*}{$\begin{array}{l}\text { Business Model } \\
\text { Dimensions } \\
\text { Value Proposition }\end{array}$} & \multicolumn{4}{|c|}{ Business Model Innovation } & \multirow{3}{*}{$\begin{array}{c}\text { Business Model } \\
\text { Design }\end{array}$} \\
\hline & \multirow{2}{*}{\multicolumn{2}{|c|}{$\begin{array}{l}\text { Business Model } \\
\text { Reconfiguration }\end{array}$}} & \multicolumn{2}{|l|}{ Business Model } & \\
\hline & & & \multicolumn{2}{|l|}{ Development } & \\
\hline & Green Value & 19 & Green Value & & Green Value \\
\hline & Proposition & & Proposition & & Proposition \\
\hline & Innovation & & Reconfiguration & & Development \\
\hline User and & Green User and & 31 & Green User and & 1 & Green User and \\
\hline Customer & Customer & & Customer & & Customer \\
\hline & Innovation & & Reconfiguration & & Development \\
\hline Value Chain & Green Value & 37 & Green Value & & Green Value \\
\hline Function & Chain Function & & Chain Function & & Chain Function \\
\hline & Innovation & & Reconfiguration & & Development \\
\hline Competence & Green & 104 & Green & 11 & Green \\
\hline & Competence & & Competence & & Competence \\
\hline & Innovation & & Reconfiguration & & Development \\
\hline Network & Green Network & 30 & Green Network & & Green Network \\
\hline & Innovation & & reconfiguration & & Development \\
\hline Value Formula & Green Value & 18 & Green Value & & Green Network \\
\hline & Formula & & Formula & & Development \\
\hline & Innovation & & Reconfiguration & & \\
\hline Relations & Green Relation & 1 & Green Relation & & Green Relation \\
\hline & Innovation & & Reconfiguration & & Development \\
\hline $\begin{array}{l}\text { Total incidents in } \\
106 \text { businesses }\end{array}$ & & 240 & & 12 & 8 \\
\hline
\end{tabular}

In our GBMI research, we distinguish between Green Business Model Innovation (Green Business Model Design and Green Business Model Reconfiguration) [22] and Green Business Model Development. Green Business model development focus on implementation and introduction, growth, maturity and decline phase of the GBM's with classical BM development tactical parameters, tools and actions. Green Business Model Development covers also the continuous improvement of GBM's, when the are operating. We found very few GBM cases that had entered yet the GBM development phase [12 incidence], often because the businesses could not find enough efficiency in investing green. Those we found were primarily into the introduction phase and mostly focusing on initial promotion and improvement of GBMs and especially focusing on branding their business or BM on being green. Very few were "full hearted" in this initiative. We also found very few GBM in the GBM Design phase [8 incidence] indicating that much GBMI are not doing radical or disruptive GBM. 
Table 3 Single green business model innovation related to business model innovation levels

\begin{tabular}{|c|c|c|c|c|c|}
\hline \multirow{3}{*}{$\begin{array}{l}\text { Business Model } \\
\text { Innovation Levels } \\
\text { Business Model } \\
\text { Component - }\end{array}$} & \multicolumn{4}{|c|}{ Green Business Model Innovation } & \multirow{3}{*}{$\begin{array}{l}\text { Business Model } \\
\text { Design }\end{array}$} \\
\hline & \multirow{2}{*}{\multicolumn{2}{|c|}{$\begin{array}{l}\text { Business Model } \\
\text { Reconfiguration }\end{array}$}} & \multirow{2}{*}{\multicolumn{2}{|c|}{$\begin{array}{c}\text { Green Business } \\
\text { Model Development }\end{array}$}} & \\
\hline & & & & & \\
\hline $\begin{array}{l}\text { Business Model } \\
\text { Component - }\end{array}$ & $\begin{array}{l}\text { Green Business } \\
\text { Model } \\
\text { Component } \\
\text { Innovation }\end{array}$ & 104 & $\begin{array}{l}\text { Green Business } \\
\text { Model } \\
\text { Component } \\
\text { Reconfiguration }\end{array}$ & 11 & $\begin{array}{l}\text { Green Business } \\
\text { Model } \\
\text { Component } \\
\text { Development }\end{array}$ \\
\hline $\begin{array}{l}\text { Business Model } \\
\text { Dimension - }\end{array}$ & $\begin{array}{l}\text { Green Business } \\
\text { Model } \\
\text { Dimension } \\
\text { Innovation }\end{array}$ & 1 & $\begin{array}{l}\text { Green Business } \\
\text { Model } \\
\text { Dimension } \\
\text { Reconfiguration }\end{array}$ & & $\begin{array}{l}\text { Green Business } \\
\text { Model } \\
\text { Dimension } \\
\text { Development }\end{array}$ \\
\hline $\begin{array}{l}\text { Single Business } \\
\text { Model }\end{array}$ & $\begin{array}{l}\text { Green Business } \\
\text { Model } \\
\text { Innovation }\end{array}$ & 46 & $\begin{array}{l}\text { Green Business } \\
\text { Model } \\
\text { Reconfiguration }\end{array}$ & 2 & $\begin{array}{l}\text { Green Business } \\
\text { Model } \\
\text { Development }\end{array}$ \\
\hline $\begin{array}{l}\text { Business Model } \\
\text { Portfolio }\end{array}$ & $\begin{array}{l}\text { Green Business } \\
\text { Model Portfolio } \\
\text { Innovation }\end{array}$ & 3 & $\begin{array}{l}\text { Green Business } \\
\text { Model Portfolio } \\
\text { Reconfiguration }\end{array}$ & & $\begin{array}{l}\text { Green Business } \\
\text { Model Portfolio } \\
\text { Development }\end{array}$ \\
\hline Business & $\begin{array}{l}\text { Green Business } \\
\text { Innovation }\end{array}$ & 43 & $\begin{array}{l}\text { Green Business } \\
\text { Reconfiguration }\end{array}$ & 3 & $\begin{array}{l}\text { Green Business } \\
\text { Development }\end{array}$ \\
\hline $\begin{array}{l}\text { Business Model } \\
\text { Ecosystem [14] }\end{array}$ & $\begin{array}{l}\text { Green Business } \\
\text { Model } \\
\text { Ecosystem } \\
\text { Innovation }\end{array}$ & 42 & $\begin{array}{l}\text { Green Business } \\
\text { Model } \\
\text { Ecosystem } \\
\text { Reconfiguration }\end{array}$ & 1 & $\begin{array}{l}\text { Green Business } \\
\text { Model } \\
\text { Ecosystem } \\
\text { Development }\end{array}$ \\
\hline $\begin{array}{l}\text { Business Model } \\
\text { Innovation } \\
\text { Process }\end{array}$ & $\begin{array}{l}\text { Green Business } \\
\text { Model Process } \\
\text { Innovation }\end{array}$ & 2 & $\begin{array}{l}\text { Green Business } \\
\text { Model Process } \\
\text { Reconfiguration }\end{array}$ & & $\begin{array}{l}\text { Green Business } \\
\text { Model Process } \\
\text { Development }\end{array}$ \\
\hline $\begin{array}{l}\text { Total incidents in } \\
106 \text { businesses }\end{array}$ & & 241 & & 17 & 8 \\
\hline
\end{tabular}

There is still not much validated research that document the efficiency of these GBMI projects and developments. Some of the GBMI and Development projects were carried out due to subsidies [23] and energy cost savings but indications show that focusing on other green business model parameters e.g. material and resource savings will be able to give much higher cost savings and even value adds to the businesses.

From our investigation, we found that the businesses primarily focus on "greening" the BM competence dimension (104-incidence Table 2). The BM competence dimension consist classically of technology (productand service technology, production technology and processes technology), HR, Organisational Systems and Culture. We found that there is a 
clear overweight to focus on innovating, investing and implementing green technologies - especially green production technologies and green product and service technologies - changing into e.g. using more green material, resources and equipment. However, most business was not able to secure and measure if the product, service and production technologies were green. Several bought recycled material but often it was a mix of recycled and nonrecycled material - e.g. steel - and none was able to secure that the raw material was produced with e.g. green energy and with green production technologies. This would therefore be another promising area for advanced security technology to be involved in.

There is also an increasing focus to reduce and change resource and material consumption, reduce, recycle waste, as this Green Business Model Parameters (GBMP) [24] seems to have much impact on reducing Co2. In some case, the impact of focusing on "greening" material and resources seamed as earlier mentioned to be much higher than reducing energy and changing from black to green energy. We did not find any businesses investing in security technology for GBMI.

From our investigation of the 106 businesses GBMI and development cases, we found that most GBMI projects are taking place on BMI Component layer and BM reconfiguration level - equal to change of existing AS IS BM's. This indicates, that the big potential in the Business model ecosystem for GBMI security technologies in the businesses is on reconfiguration of AS IS BM's. Further we found that GBMI is taking place at a very small, bottom, and limited level in the businesses. We found that majority of businesses are limiting their GBMI to greening a single business model (46 incidences) and mostly reconfiguration of these single business models - not in particular designing GBM's. This indicates that businesses have not yet fully adapted the GBM approach and GBMI into the entire and higher levels of the business - and the new BMI area. It indicates that most BMI levels are not included in the GBMI - as a core of BMI in the businesses. In other words, GBMI seems still in the very early days - strategically not yet to have been embedded in to critical and larger parts/levels of the businesses. This has to be taken into consideration, when advanced wireless and security technologies are proposed to the businesses.

In our case research of the 106 businesses, we did not find many businesses "playing" the Strategic GBMI and development game. This can be wrong maybe because of lacks in our research approach and depth. However, it seemed as most businesses adapted the single green BMI strategy as seen in Table 3. This result indicates that many businesses have not strategical yet 
focus on GBMI and definitely not security and security technologies related to GBMI.

\section{Where Do Businesses Have Challenge on Green Business Model Innovation}

From the green business model cases we studied we elected 4 green business model cases that exemplifies different green business model challenges that future $6 \mathrm{G}$ wireless technologies potentially would be able to help with. The elected business cases also shows businesses that have hit "The Green Wall"they do not have solutions to how to take the next step on the green transformation. They have taken many of "the low hanging fruits" on Green Business Model Innovation journey - but now they have to take radical and disruptive steps to clime the green transformation latter. Some of the business cases are kept anonymous due to name restrictions.

\subsection{SA - Green Business Model Innovation - Reuse, Recycling Auto Parts From Scraped Cars}

The European Commission release data through agency Eurostat every year showing a End of Life Vehicle (ELVs) recycling and recovery rate. The total number of end-of-life vehicles reported have risen considerably from the mid 2000 up to today. As for compliance with targets EU Member States were required in 2015 - 2016 to meet EU's general rates for reuse and recycling of more than or equal to $85 \%$ and for reuse and recovery of more than or equal to $95 \%$ by an average weight per vehicle.

SA is a business that receive old used vehicles, which is no longer functional but may be repaired, dismantled for spare parts or completely demolished. The vehicles are carefully classified, when arriving at the business and all environmental treatments according to Danish environmental rules are carried out..

All vehicles are divided into different business models at SA as for

- BM1 Repair and serviced - Cars to be sold and used again

- BM 2. Dismantled into spare parts that can be sold and reused in other cars

- BM3. Completely Demolished and separated into different liquid, materials (iron, cobber, plastic, seatbelts, airbags, 


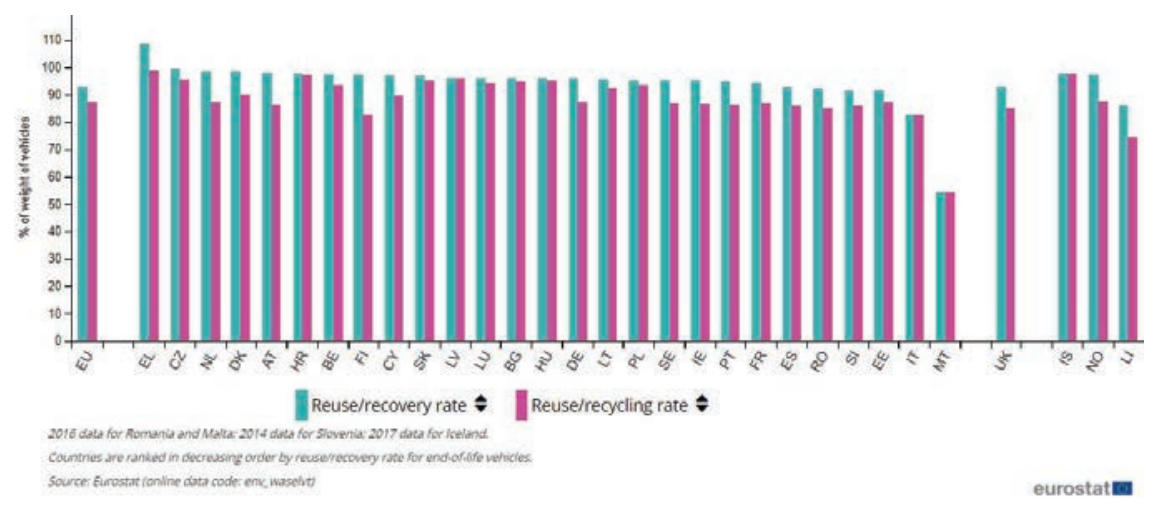

Figure 7 End-of-life vehicle statistics Eurostats [25].
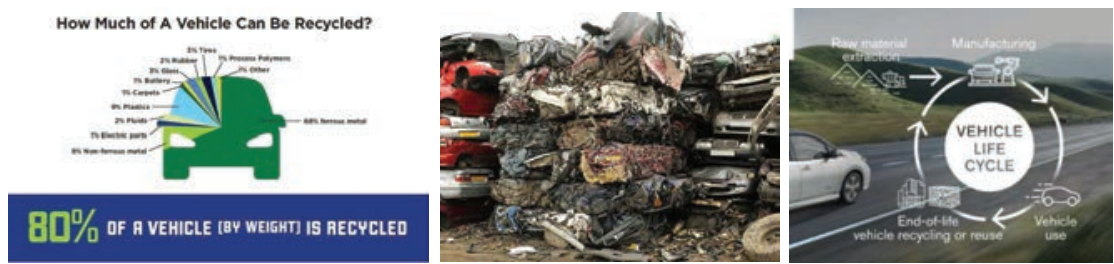

Figure 8 Different example of treatment of used cars and how much of a vehicle can be recycled.

SA is a modern auto recycling business with focus on environment, circular economy and green business modelling. SA have more than 30.000 quality tested spare parts on stock and have access to more than 3 mio. Spare parts via a shared storage by collaborating businesses in the scrap car Business Model Ecosystem [19]. SA is ISO-14001 certified, which secure that all environmental rules are meet by SA and SA won the price "The Auto recycler of the year" because of SA's green profile. SA is able to think innovative and SA are ready for change. SA want to be the greenest car recycling business. This means that $\mathrm{SA}$ are much interested to invest in green business modelling supported by advanced technology. However SA have several challenges in this case.

Reusing used parts and selling materials (iron, copper, e.g.) is a big business for SA. However, much from the vehicles are still not possible to reuse and circulate as classification has still to be done by hand, which is extremely cost consuming. If it was possible through advanced technology to classify the parts in the vehicle precisely once the car arrives and attach 
these to documented secure classifications that the business, customers and authorities could believe in - have trust in - then it would be possible to dismantle faster, more safe and according to rules and regulations in the used vehicles business model ecosystem and with much higher efficiency. Impact on most green business parameters would be possible to achieve. Large databases from original car manufactures already exist and can be accessed but SA needs advanced technologies to support access to these data bases and link it to the specific vehicles. Not all information is available in real time and the individual components in the used cars are not, at the moment, able to communicate to SA system and employees. More and more new cars to some extend are able to do this communication. Further many used cars can not be tracked with life cycle of the car - repair and service report, LCA reports of materials and components inside the car. This prevent SA to do a efficient handling of the used vehicles.

Large amount of plastic in cars are difficult to recycle as they have different kind of mix materials included - inclusive inflammable chemicals - when released heavily poisoning. In these business cases advanced technologies could help to identify these and continuously track and trace these so they can be handle with care - with a green approach.

\subsection{HA Woodservice - Green Business Model Innovation and Biodiversity}

HA Woodservice is in the business of maintaining and servicing woods for private and public wood owners. Further HA Wood service maintain green areas around different businesses. Lately biodiversity has been a hot topic in the green business model innovation debate and more and more businesses - especially public businesses are forced to take biodiversity into their green business model innovation. More and more woods and green areas are transferred into different types of planting, treatment and maintenance practice that meet the customers and societies requirement for Biodiversity. HA Woodservice face in this sense more and more restrictions on how to maintain woods and green areas in a green way and still commercialize on behalf of e.g. the wood in the forest. At the same time documentation have to be more and more precise and detailed. E.g. every tree planted should be GPS - positioned.

In this sense advanced technologies are needed to help on documentation of treatment, use of machines and treatment methods, documentation of biodiversity - number and types of insects, plants, air quality, $\mathrm{Co} 2$ emission 

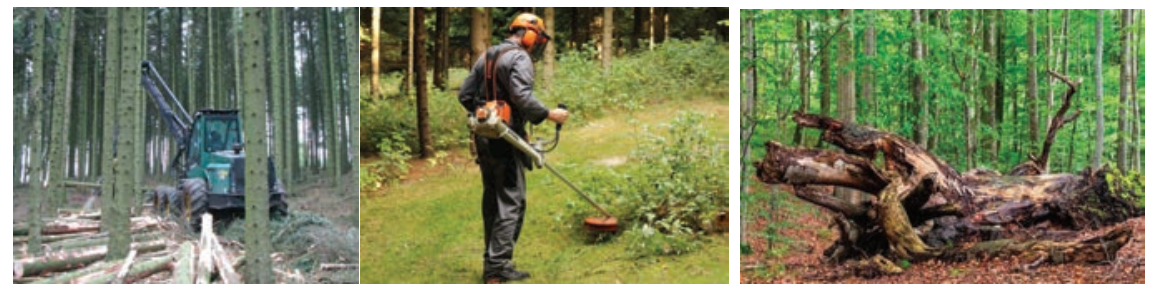

Figure 9 Forrest and green field maintenance securing biodiversity.

pr. plant e.g. Today many green business biodiversity initiatives are made on behalf of earlier research results and estimates - sometimes driven by strong believes on how biodiversity visually look likes. This can lead to large damage to the forests and further inefficiency of doing forests and green field business. Further advanced technologies could help on guiding people around the forrets in areas that are available for public visit, turismo, sports e.g. so wildlife, humans and wood businesses can live in symbiosis. Often biodiversity and business are considered not to be able to go in symbiosis but new green multi business models for this BMES and related businesses seems to be able to value each other. However much more secure and real time documentation is needed to verify what biodiversity initiatives really matters and can working in symbiosis with professional wood and green field business.

\subsection{Liqtech - Cleaning and Reuse of Waste Water}

Liqtech is specialized in developing and manufacturing unique and patented ceramic silicon carbide filters and membranes. Liqtech Ceramics has made high-value, high-performance products for liquid and gas filtration for more than two decades. Liqtech is specialized in two business model portfolio areas: ceramic membranes for liquid filtration systems and diesel particulate filters (DPFs) to control soot exhaust particles from diesel engines.

LiqTech Water are specialists in water treatment technologies and provide end-to-end service with complete in-house engineering capabilities. By integrating unique ceramic membranes into innovative water treatment systems for various business model ecosystems Liqtech can provide sustainable operation for customers requirements. Liqtech is a leading international player when it comes to removing suspended solids, oil and grease, pathogens, and heavy metals from water.

Liqtech faces challenge to classify in realtime fast, secure and efficient content of liquid and especially waste liquid. Further track and trace of the 

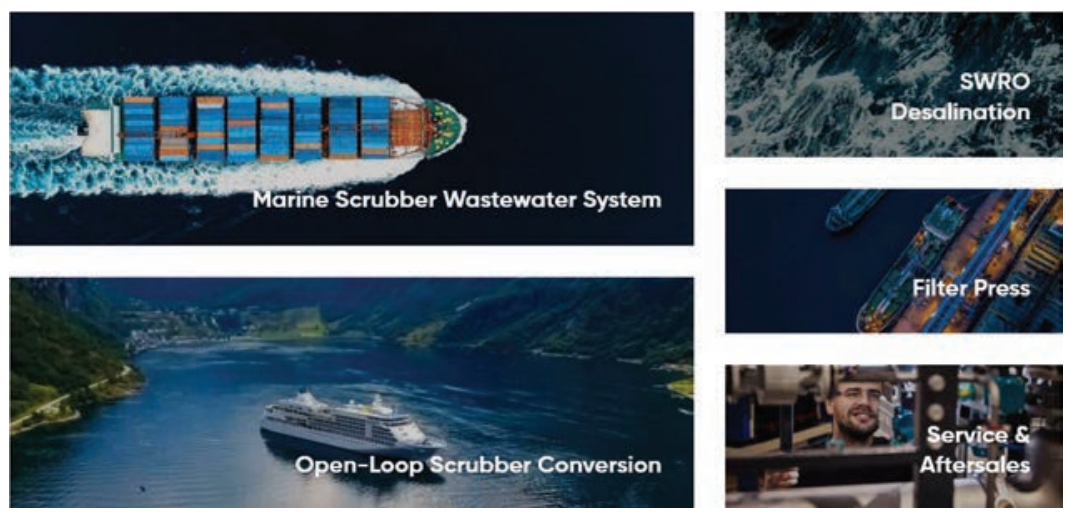

Figure 10 Liqtech waste water solution [26].
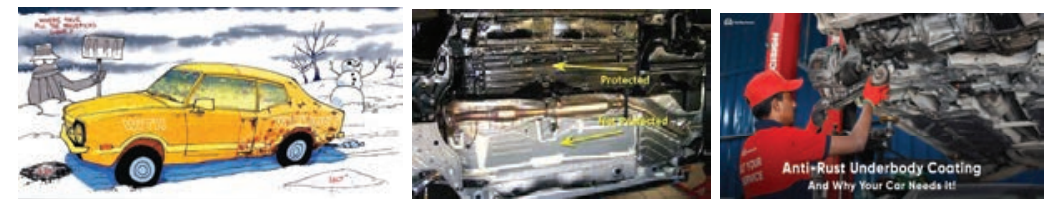

Figure 11 Antirust protection with or without.

treated waste liquid, customers and networks treatment of the treated liquid could secure waste liquid from "cradle to cradle". Advanced technologies that could provide these value propositions safe and secure would open up to enormous GBM potentials. Especially if advanced and secure measurements system would be possible to innovate and develop so that customers and regulators would be able to get secure, valid and reliable data on the waste liquid, treated waste liquid. Further it could open up to further mining of the waste liquid, treated liquid and could give customers that are interested in buying whole or part of the treated waste liquid security of what they really were buying.

\subsection{LHG - Group - Securing Vehicles and Auto Parts for a Longer Life Time}

Antirust protection of cars have for many years been well known as securing and prolonging lifetime of cars and auto parts on a car as seen in Figure 11.

Previously there have been a long tradition to anti rust protect cars but as buying behavior of cars have changed into commodities like BM's furniture's, lamps, clothing - e.g. new BM's of financing cars have appeared 
to be very popular. BM's as private leasing and rent push to the tendency that customers becomes more and more motivate to change cars more frequently. Thereby cars are changed more often, the lifecycle of cars shrinks in western countries and car owners do not see any reasons to take care of their cars.

At the same time new rust protection products have been introduced based on water and LHG group have innovated a new system that enables LHG to take back used antirust liquid from the treatment process and recycle this for new antirust liquid.

LHG group wants continuously to make the business greener and one BM concept is to influence the BMES for used cars to treat more cars with antirust protection to increase the life time of a car. Hereby the use of material and resources can be reduced. However this is a very complicated matter as it do not only involve GBM parameters but also customers demands for new design, style and BM's. Further other BM's - new and changed finance BM types and government taxes and subsidies push against more GBMI in this BMES.

6G and security technologies can in this anti rust BMES play different roles. Firstly help to identify which parts of the car has been anti rust protected and not. Secondly the advanced technologies would be able to measure and communicate to the user and customers how long the part of the car - or even the whole car - can be used more before antirust have to be given again to the car. This could impact the life cycle of a car, so cars would be used longer time which could result in major savings on Co2. Some claims [that a new car will use about $5500 \mathrm{~kg}$ of $\mathrm{Co} 2$ to be produced. A antirust treatment would only use $3,2 \mathrm{~kg}$ Co2.The british ECI research group at Oxford University [27] document, that production of electrical vehicles in average have an emission of 9000 ton of $\mathrm{Co}$. They found that differnt car types total emission of $\mathrm{CO} 2$ realted to the total cars life cycle - LCA analysis shows that keeping old petrol- and diesel cars on the streets are a greener choice to society before the cars come into the Business Model ecosystem. When the electrical cars enter the Business Model Ecosystem then they give less $\mathrm{Co} 2$ impact than petrol and diesel cars.

\section{Discussion}

The paper discus different documentation and security challenges related to Green Multi Business Model Innovation and Development. Green Business Models and Green Business Model Innovation needs better and more advanced technologies to document green business models more precise and 
in realtime. In this sense security and trust to measurement and measurement tools are highly important to future GBM customers, network, businesses and societies. Mistrust to GBM's, GBM standards and certificates will lead to slower green transformation and directly have impact on climate together with the speed to reaching the green transformation goals of businesses and society.

Security perspective and advanced technology innovation can contribute very much to research in different fields of GBMI offering future research directions for advanced wireless and related technologies. A radical new green business model system embedded with secure 6G based Green Multi Business Model Innovation approach is highly important both to practice but also to academic development in the green business model innovation field. 6G revolutionary technology innovation and developments can push reconfiguration of black AS IS BM into becoming 'greener' and at the same time take into account environmental concerns.

GBMI challenge previous classical linear business model frameworks and business modelist - both classical, circular and sustainable business modelist [19] - because business now really are forced to think, create, capture, deliver, act and do green business model innovation with more business models. Further this can be measured and with secure measurement of GBM and GBMI within realtime.

A variety of advanced $6 \mathrm{G}$ based and new security technologies will be able to help and support the implementation and roll out of GBM and GBMI. In itself expected $6 \mathrm{G}$ technologies and the above mentioned characteristics of future $6 \mathrm{G}$ technologies and security technologies - Section 1 in this paper will in itself meet the requirements of GBM and GBMI. Especially the precision and sensor technologies together with the higher speed of transforming and transmitting the data will improve the measurement of GBM's and GBMI.

\section{Conclusion}

The paper presents the strategic sources and security challenges and opportunities for $6 \mathrm{G}$ technologies and related security technologies in innovating green business models with a multi business model innovation approach. The green multi business model strategies - proposed and exemplified on behalf of observations 106 green business model innovation cases and elected 5 deeper green business model innovation case studies - introducing some of the strategic green business model innovation initiative and related security 
challenges in green multi business model innovation and development. The paper is built on top of a previous review of green single business model innovation literature and practice in businesses, which shows very clearly that green business model innovation at the moment is taking mostly place on a competence BM dimension and on a very technical product and production technology area. Green Business Model Innovation is further taking place at a very low business model innovation level in the businesses and security is not a key focus point in the businesses. Our deeper investigation of 5 green business model innovation cases with the goal of achieving greater understanding of security challenges and potentials for future wireless technologies related to strategic Green Multi Business Model Innovation and Development found 5 security areas that needs more advanced technologies to improve value of green multi business model innovation. Firstly the Green Business Model Innovation and reuse, recycling security challenge. Trough advanced technology businesses could enable fast and more precise classification of the parts in the vehicle once the old cars arrives at the business. With improved documented secure classifications the businesses, customers and authorities could believe in - gain trust to - classifications and green business model innovation. Then it would be possible to dismantle faster, more safe and according to rules and regulations in the used car business model ecosystem and thereby produce green business models with much higher efficiency. Much higher impact on most green business parameters would then be the result.

The individual components in many business models - in our study of used cars - showed that the car parts are not at the moment able "to communicate" with the green business model systems. Many used cars can further not be tracked with life cycle of the car - repair and service reports and LCA of materials and components inside the car.

Secondly advanced technologies could further help on documentation green business model parameter Biodiversity and related treatment, use of machines and treatment methods, documentation of biodiversity - number and types of insects, plants, air quality, $\mathrm{Co} 2$ emission e.g in the forrest and green business model service ecosystem.

Thirdly advanced and secure measurements system would be able to secure, valid and show reliable data on the waste liquid and treated waste liquid. It could open up to "mining" of waste liquid, treated liquid and could give customers security of what they really were buying.

Fourthly to make the business greener a green business model concept has to influence the BMES's it is related to vertically. E.g. used cars and other BM 
Business Model Ecosystem har to treat old products better - e.g. more new and old cars should be treated with antirust protection to increase the life time of cars - the LCA of a BM. Hereby the use of material and resources can be reduced, $\mathrm{Co} 2$ emission can be reduced and BM's can become greener over their life time. However this is a very complicated matter and thing to document as it do not only involve green business model parameters but also customers demands for new design, style and BM's. Further other BM's new and changed finance BM types and government taxes and subsidies push in this case often against more green business model innovation. Advanced technology and security technology could however document and track that customers are keeping their BM's longer and advanced 6G technologies could potentially make old BM's have "a new digital and virtual surface", so that they could be used for a longer time.

Most businesses we studied did not have strategical focus on security and security technologies related to green business model innovation. Further there is a strong indication in our research that GBMI security technologies in the businesses have to focus more on reconfiguration of AS IS BM's transforming AS IS BM's into greener AS IS BM's - than new TO BE green business models. We finally found that GBMI is taking place at a very small, bottom and limited level in the businesses, which indicates that advanced security technologies have to be implemented and focused on small parts and lower level of the businesses business models and business model innovation levels.

\section{Further Research}

The researchers intend to investigate further security in Green Multi Business Model and Single Green Business Model Innovation in Nordic Countries through the EU KASK GreenBizz project - www.GREENBIZZ.COM. More than 60 business cases in Norway, Sweden and Denmark will be objects to deeper investigated. Further 780 businesses in Central Region Denmark is objects to further investigated in 2021 and 2022.

\section{References}

[1] Gillenwater, Michael (2020) CEO Greenhouse Management Institute ht tps://ghginstitute.org/people/michael-gillenwater/ 
[2] Beslik Sasja (2020) CEO Sustainable Investment Swizz Banc J. Safra Sarasin - file:///C:/Users/au196408/Downloads/SustainableInvestments Quarterly_20200103_en.pdf

[3] https://ec.europa.eu/commission/presscorner/detail/fr/speech_19_6749

[4] World Commission on Environment and Development (1987). Our Common Future. Oxford: Oxford University Press. p. 27. ISBN 019282080X.

[5] UN 17 goals - https://sdgs.un.org/goals

[6] Bocken, N.M.P et all (2014) A literature and practice review to develop sustainable business model archetypes - Journal of Cleaner Production Volume 65, 15 February 2014, Pages 42-56

[7] Bocken, Nancy; Schuit, Cheyenne; Kraaijenhagen, Christiaan (2018) Experimenting with a circular business model: Lessons from eight cases Environmental Innovation and Societal Transitions DOI: 10.1016/j.eist .2018.02.0012018

[8] Delmas, M. A., Burbano, V. C. (2011). The drivers of greenwashing. California Management Review, 54, 64-87

[9] The Greenbizz project - EU Interreg. Kask - https://www.greenbizz.eu/

[10] ECSMV - project - https://ecsmv.dk/

[11] SETs II - https://www.sets-kask.eu/en/

[12] Circit project - https://ecodesign.dtu.dk/circit

[13] Greenest City Vancover 2020 - https://vancouver.ca/files/cov/Greenestcity-action-plan.pdf

[14] Monica project - https://www.monica-project.eu/

[15] Sommer, A (2012) Managing Green Business Model Transformations Springer Verlag ISBN 978-3-642-28848-7

[16] EU Green Deal Call https://ec.europa.eu/commission/presscorner/detail /en/ip_20_1669

[17] Lindgren P. et al. (2020) "Green Business Models literature study presented at WWRF workshop" - How can future wireless Technology support Green Business Model Innovation? Online WWRF seminar 13:45-18:00 The 21 October 2020

[18] Lindgren, P. (2021) The Green Multi Business Model Innovation Brain Journal of Mobile Multi Media River Publishers

[19] Lindgren, P. (2016) The business model ecosystem. Journal of Multi Business Model Innovation and Technology, 4, no. 2, 61-110

[20] Project Drawdown https://drawdown.org/

[21] Lindgren P., (2018) The Multi Business Model Innovation Approach Part 1 River Publishers 
[22] Lorenzo, M., Christopher L. Tucci, Allan Afuah (2017) a critical assessment of business model research Academy of Management Annals 2017, Vol. 11, No. 1, 73-104. https://doi.org/10.5465/annals.2014.0072

[23] https://smvdigital.dk/groen-tilskudspulje/tilskud-til-privat-raadgivning -paa-100-000-kr

[24] Lindgren P. (2021) A Scoping Review and Framework of Green Business Models Related to Future Wireless Technology: Bridging Green Business Models to Future Wireless Technology Journal of Journal of NBICT, Vol. 1, 1-34. doi: 10.13052/nbjict1902-097X.2020.016

[25] End-of-life vehicle statistics Eurostats - https://ec.europa.eu/eurostat/st atistics-explained/index.php?title=End-of-life_vehicle_statistics

[26] Liqtech water https://liqtech.com/water/marine/

[27] Dixon James et all (2021) Environmental Change Institute at Oxford University https://www.eci.ox.ac.uk/people/jdixon.html

\section{Biography}

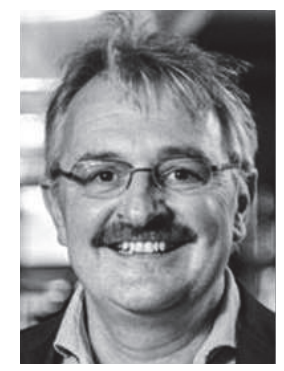

Peter Lindgren Peter Lindgren holds a full Professorship in Multi business model and Technology innovation at Aarhus University, Denmark - Business development and technology innovation and is Vice President of CTIF Global Capsule (CGC). He is Director of CTIF Global Capsule/MBIT Research Center at Aarhus University - Business Development and Technology and is member of Research Committee at Aarhus University - BSS.

He has researched and worked with network based high speed innovation since 2000. He has been head of Studies for Master in Engineering - Business Development and Technology at Aarhus University from 2014 - 2016 and member of the management group at Aarhus University Btech $2014-2018$. He has been researcher at Politechnico di Milano in Italy (2002/03), Stanford University, USA (2010/11), University Tor Vergata, Italy (2016/2017) and has 
in the time period 2007 - 2011. He has been the founder and Center Manager of International Center for Innovation www.ici.aau.dk at Aalborg University, founder of the MBIT research group and lab - http://btech.au.dk/forskning/ mbit/ - and is cofounder of CTIF Global Capsule - www.ctifglobalcapsule. org.

He has worked as researcher in many different multi business model and technology innovations projects and knowledge networks among others E100 - http://www.entovation.com/kleadmap/, Stanford University project Peace Innovation Lab http://captology.stanford.edu/projects/peace-inno vation.html, The Nordic Women in business project - www.womeninb usiness.dk/, The Center for TeleInFrastruktur (CTIF), FP7 project about "multi business model innovation in the clouds" - www.Neffics.eu, EU Kask project - www.Biogas2020.se, Central Project, Motor5G, Recombine, Greenbizz. He is cofounder of five startup businesses amongst others www.thebeebusiness.com, www.thedigibusiness.com, www.vdmbee.com.

$\mathrm{He}$ is author to several articles and books about business model innovation in networks and Emerging Business Models. He has an entrepreneurial and interdisciplinary approach to research. His research interests are multi business model and technology innovation in interdisciplinary networks, multi business model typologies, sensing-, persuasive- and virtual-business models. He has been serving as quest editor and reviewer for many highly-respected journals and conferences - "Journal of Personal Wireless Communication"; "Journal of Multi Media application"; "WPMC", "IFKAD", "CInet", "WWRF", "NBICT", "ITAIS". 
